\title{
ANALYSIS OF THE PRODUCTION CAPACITY FROM A HARVESTER IN THE FOREST IN OWN AND OUTSOURCED MODULES. ${ }^{1}$
}

\author{
Leonardo Cassani Lacerda ${ }^{2}$, Nilton Cesar Fiedler ${ }^{3 *}$, José Franklim Chichorro ${ }^{3}$, Luciano José Minette ${ }^{4}$ and \\ Flávio Cipriano de Assis do Carmo ${ }^{5}$

\footnotetext{
${ }^{1}$ Received on 15.05.2015 accepted for publication on 16.03.2017.

${ }^{2}$ Universidade Federal do Espírito Santo, Programa de Pós-Graduação em Ciências Florestais, Jerônimo Monteiro, Espírito Santo, Brasil. E-mail: <leocassani@hotmail.com>.

${ }^{3}$ Universidade Federal do Espírito Santo, Departamento de Ciências Florestais e da madeira, Jerônimo Monteiro, Espírito Santo, Brasil.E-mail: <fiedler@pq.cnpq.br>and<jfufes@gmail.com>.

${ }^{4}$ Universidade Federal de Viçosa, Departamento de Engenharia de Produção e Mecânica, Viçosa, Minas Gerais, Brasil. E-mail: <minette@ufv.b>.

${ }^{5}$ Universidade Federal do Espírito Santo, Programa de Pós-Graduação em Ciências Florestais, Jerônimo Monteiro, Espírito Santo, Brasil. E-mail: <flaviocipriano@hotmail.com>.

*Corresponding author.
}

\begin{abstract}
This study aimed to perform a machine operational analyses used on the eucalyptus mechanized harvest, in four different regions of the Espirito Santo and Bahia states. The activities were performed by own and outsourced labor, the regions had a similar climate condition, relieve and similar machine, the harvest forest tractor. The mechanical disponibility, operational efficiency, machine production was analyzed during a 12 months period in the field and by the operational output from the database from 60 own machines and 60 outsourced machines in each one from de four regions (120 machines). Based on the results, it was observed that in the own module and the outsourced, variables were the mechanical disponibility operational efficiency and technical disponibility did not have different during the study period, among the regions. The executed work with own machines had a higher production when compared to the outsourced, with exception of the regions $\mathrm{A}$ and $\mathrm{C}$. The total volume produced per year by the cut forest with the own machines were higher than $1.234 .310 \mathrm{~m}^{3}$ to the total volume cut with outsourced machines, showing a higher operational efficiency when the harvest was made with an own model.
\end{abstract}

Keywords: Forest cut; Forest operation and Technical; Outsourced.

\section{ANALISE DA CAPACIDADE DE PRODUÇÃO DO HARVESTER NO CORTE FLORESTAL EM MÓDULOS PRÓPRIOS E TERCEIRIZADOS}

\begin{abstract}
RESUMO - O objetivo deste estudo foi realizar uma análise operacional das máquinas utilizadas na colheita mecanizada de eucalipto, em quatro diferentes regionais nos estados do Espírito Santo e Bahia. Os serviços eram realizados por meio de mão de obra própria e terceirizada, em que estas utilizavam-se de condições climáticas, relevo e maquinários semelhantes, sendo estudado o trator florestal harvester. Avaliou-se durante os 12 meses, a disponibilidade mecânica, a disponibilidade técnica, a eficiência operacional e a produção das máquinas, por meio de coletas de dados em campo e em banco de dados dos rendimentos operacionais de 60 máquinas próprias e 60 terceirizadas em cada uma das quatro regionais (120 máquinas). De acordo com os resultados, observou-se que tanto no módulo próprio quanto no terceirizado as variáveis disponibilidade mecânica, eficiência operacional e disponibilidade técnica não se diferenciaram entre o período do estudo, ocorrendo somente entre as regionais. Os serviços executados com maquinários próprios tiveram produção superiores aos terceirizados, com exceção apenas da variável disponibilidade mecânica nas regionais $A$ e C. O volume total produzido por ano pelas florestas cortadas com maquinário próprio superou em 1.234.310 $m^{3}$ ao volume total cortado por maquinário terceirizado, denotando maior eficiência operacional quando a colheita foi feita com módulo próprio.
\end{abstract}

Palavras-chave: Corte florestal; Técnicas e operações florestais; Terceirização. 


\section{INTRODUCTION}

Until the late $60 \mathrm{~s}$, the forest harvest in Brazil was almost exclusively done in native forest, and at the most part of the times in a predatory form. With the fast grown forest and a creation of government fiscal incentive policy, another impulse was given to the forest sector (Machado, 2014). From then on, an expansion of the sector happened, allowing the sector recognition by the society for its contribution to the economic, social and environmental on the country. Trough this fact, Schuchovski (2003) said that the planted forest, specifically the Eucalyptus genus, are essential feedstock, integrating different productive chain, as an example: cellulose and paper; Steel industry; energy; Panels; Furniture and solid wood, making a great contribution to work creation and income.

The forest harvest is an activity with a special attention from the companies given its high representativeness in production costs, a high risk and an elevated demand for specialized labor, which is often outsourced, trying to meet the involved demand.

According to Machado \& Lopes (2000) and Silva et al. (2014), the harvest and transport activity has a great economic importance to the forest sector, and it should be designed to reduce that costs, that can represent more than $50 \%$ of the total cost of the wood present in the industry. On that way, is very important to verify the best operational system, outsourced or own, that would result in a lower cost by produced volume, considering the financial resources available to those activities (Carmo et al., 2015).

To achieve goals and the maximum production, many companies for failing to achieve these goals are forced to hire labor outside their fields. In this way, companies have been adopting outsourced labor aiming to reduce costs, once it has been decreasing their worker board resulting in a reduction on responsibilities with Social and labor responsibility. Moreover, it should be considered that those contracts offer risks in relation to the service discontinuance provision and quality standard guarantee, which may lead to a reduction of costs or damages (Machado et al., 2009).

According to Leite (2002), the determining factor to the outsourced forestal harvest was: reduction in the cost of labor and social responsibility, more flexibility and agility, and reduction of union strength. So, studies that serve as tools to support decision making in the

\footnotetext{
Revista Árvore. 2017; 41(1):e410120
}

planning of operations are important, highlighting investigations that treat outsourcing as an object of study in the qualitative and quantitative areas, to clarify their advantages and disadvantages and verify the real attractiveness of the outsourced regime over the own regime in different operating scenarios.

This study aimed to perform a capacity analyses of the forest tractor in the cutting of eucalyptus stands in own and outsourced modules, contributing as a base tool for forest operations management.

\section{MATERIALS AND METHODS}

The research was performed in fields of hydribs clones between Eucalyptus urophylla x Eucalyptus grandis distributed in four regions, two (Region A and B) on the Espirito Santo state, the Regional A was composed of the cities Aracruz, Fundão. Ibiraçu, João Neiva and Linhares and the Region B with the cities São Mateu, Conceição da Barra and Pedro Canário, and two (Region C and D) at the Southern of the Bahia state, the $\mathrm{C}$ region is formed by the cities of Mucuri and Nova Viçosa and region D by the cities Caravelas, Alcobaca and Teixeira de Freitas.

The areas where the study was performed are located in a relieve plain to slight wavy (the maximum slope at $5 \%$ ), altitudes between 10 and $50 \mathrm{~m}$. The wood used in the four regions had the age cut from five to six years old, average height $20 \mathrm{~m}$, a $3 \times 2 \mathrm{~m}$ grid with approximately 1667 trees per hectare, and volume ranging from 0,16 and $0,33 \mathrm{~m} 3$ per tree.

\subsection{Wood harvest system.}

The system that was used by the company is the cut-to-length with the mechanized operation to falling and processing. To the cut (falling and processing) the operation was realized using a harvester doing the following operations: falling, tree decoy, debarking (removal of the crown at the end of the disarrangement), tracing that consist of the cutting of three logs with six meters, and stacking (formation of small piles after tracing).

\subsection{Characterization of the evaluated machine}

The harvester work sequence was constituted by the positioning of the machine head in the tree, falling (trunk sectioning), directing the fall, disking, falling, tree decoy, debarking, Stopping (removal of the crown at the end of the decking), tracing consisting of sectioning 
the shaft in dimensions of six meters; And stacking (formation of small piles after tracing)., degrading, tracing and -. The work operation procedure was made by the cut of four lines of trees, the 6-meter length wood logs were deposited in piles between the first and second line of the cut axis.

At Table 1, it is described the technical characteristic of the machine model that was evaluated.

\subsection{Data collection}

The data was obtained from the database provided by the company, containing values from the operation time, regional, type of labor and machine (own or outsourced), during the period from January to December 2013.

\subsection{Technical Analyses.}

To the machine performance evaluation, 12 wood harvest modules were analyzed, six of them were made by machines owned by the company with six outsourced. Each module was composed of ten machines, so, in total data was obtained from a total of 120 machines analyzed under the same operating conditions.

To evaluate the operational output from the forest harvest, the operational cycle from the machines was divided into falling, processing, moving, and interruption (Table 2).

\subsection{Mechanical disponibility}

The mechanical disponibility is defined by the work time percentage that the machine is mechanically able to operate a productive work, not considering, the time that the machine is on repair or maintenance (Oliveira et al., 2009).

To make the calculus, the mechanical disponibility was obtained by the equation 1 from Machado (2014).

Table 1 - Model Specifications harvester evaluated.

Tabela 1 - Especificações técnicas do modelo harvester avaliado.

\begin{tabular}{|c|c|}
\hline Item & Basic Machine Characteristics \\
\hline Cabin rotation & $360^{\circ}$ \\
\hline Operational weight $(\mathrm{kg})$ & 21.000 \\
\hline Engine & $\begin{array}{c}\text { E-1 six-cylinder, turbocharged aftercooler, four strokes, } \\
\text { water cooled, direct injection and } 2000 \mathrm{rpm} \text {. }\end{array}$ \\
\hline Engine Power (HP) & 155 \\
\hline Maximum velocity $(\mathrm{km} / \mathrm{h})$ & 5,5 \\
\hline Arm reach $(\mathrm{m})$ & 9,38 \\
\hline Rolled & Conveyor with central frame in "X." \\
\hline Item & Característica do cabeçote \\
\hline Operation weight (kg) & 1.600 \\
\hline Maximum hydraulic pressure (Mpa) & 28 \\
\hline Number of decking knives & 6 \\
\hline Sabre $(\mathrm{cm})$ & 82,5 \\
\hline Type of feed roller & Non-slip steel or rubber \\
\hline Gross power supply $(\mathrm{kN})$ & 30,8 \\
\hline Cutting diameter $(\mathrm{mm})$ & 700 \\
\hline Cutting type & Sabre with chain \\
\hline Cutting diameter $(\mathrm{cm})$ & 35 \\
\hline
\end{tabular}

Table 2 - Characterisation of the operating cycle of the machines evaluated in the collection system.

Tabela 2 - Caracterização do ciclo operacional das máquinas avaliadas.

\begin{tabular}{ll}
\hline Falling & Consist in the search and tree \\
\hline Processing & $\begin{array}{l}\text { Consist in desgalhamento, descascamento, traçamento, destopamento e empilhamento da } \\
\text { madeira no talhão. }\end{array}$ \\
\hline Moving & $\begin{array}{l}\text { Consist on the moving since the final position from the last point at the cycle and the positioning } \\
\text { of the machine head at the next tree to be cut. }\end{array}$ \\
\hline Interruption & $\begin{array}{l}\text { Consist of the other activities non-listed before, considered as interruption operational and } \\
\text { nonoperation }\end{array}$ \\
\hline
\end{tabular}


$\mathrm{MD}=\frac{(\mathrm{H}-\mathrm{TPM})}{\mathrm{H}} \times 100$

Whereas:

$\mathrm{MD}=$ Mechanical disponibility (\%);

TPM $=$ Time of stay in preventive and corrective maintenance $(\mathrm{h})$; and

$\mathrm{H}=$ Hours scheduled for shift work (h).

\subsection{Utilization Degree}

The technical disponibility considering the time percentage that the machine effectively worked, equaling to own or outsourced work (Oliveira et al., 2009), expressed by the equation 2 .

$$
\mathrm{TD}=\frac{\text { he }}{(\text { he }+\mathrm{hp})} \times 100
$$

Whereas:

$\mathrm{DT}=$ technical disponibility $(\%)$;

$\mathrm{He}=$ actual hours of work shift (h); and

$\mathrm{Hp}=$ hours spent with operational stops (h).

\subsection{Operational Efficiency}

The operational efficiency is the time percentage that was effectively spent at work in relation to the total time scheduled for the service (Oliveira et al., 2009). So, it is calculated by the product of the mechanical disponibility time's utilization degree, as in the equation 3.

$\mathrm{OE}=\frac{\mathrm{DM} \times \mathrm{DT}}{100}$

Whereas:

$\mathrm{EO}=$ operational efficiency $(\%)$;

$\mathrm{DM}=$ mechanical disponibility (\%); and

DT $=$ technical disponibility (\%).

\subsection{Machine production determination}

The harvest production determination in cubic meters without peel per hour (m3.h-1), was performed based on the average volume per tree is given by the pre-cut inventory, the value was multiplied by the number of harvest trees, with this was obtained the total volume. On that way, the harvest production was calculated by the equation 4 :

Revista Árvore. 2017; 41(1):e410120 prod $=\frac{(n a \times v a)}{h e} P$

Whereas:

$\operatorname{prod}=$ machine production in peeled $\operatorname{wood}(\mathrm{m} 3 * \mathrm{~h}-1)$;

$n a=$ number of harvest trees (units);

$v a=$ average volume per tree $(\mathrm{m} 3)$; and

$h e=$ work effective hours $(\mathrm{h})$.

\subsection{Data analyses}

To calculate the operational mechanical disponibility, the operation efficiency and technical and production disponibility, 164.000 observation were on made on the machine performance during the period from January to December 2013, present at a company database in 12 modules (six owned and six outsourced).

The results were analyzed considering four treatments (Regions A, B, C, D) evaluated during the whole year between two different module (owned and outsourced). To compare the region means a T-test were performed at $1 \%$ probability.

\section{RESULTADOS}

Analyzing the mechanical disponibility (MD), technical disponibility (TD) and operation efficiency (OE) to falling and processing, Table 3 were made with the T-test application, comparing among the owned modules and the outsourced in the regions.

The MD difference per module owned and outsourced is showed in Figure 1, showing that the owned modules were higher than outsourced during the whole period of a high stability

\subsection{Machine Production}

Analyzing the harvest volume per month in own and outsourced modules were possible to evaluate the monthly production from the mechanical forestal harvest (Figure 2).

\section{DISCUSSION}

As showed on Table 3, only the Region A (A x A) to the DM did not have a statistical difference on the Region A (A x A) to the owned or outsourced model. Moreover the Region A, outsourced is the only one with a higher value $(83,8 \%)$ from the own service to 
Table 3 - Operating income of mechanized forest harvesting by mechanical availability, operational efficiency and technical availability for own and outsourcing modules.

Tabela 3 - Rendimentos operacionais da colheita florestal mecanizada por meio da disponibilidade mecânica, disponibilidade técnica e eficiência operacional para os módulos próprio e terceirizados.

\begin{tabular}{|c|c|c|c|c|c|c|c|c|c|}
\hline \multirow[t]{2}{*}{ Regional } & \multicolumn{3}{|c|}{ Mechanical Disponibility(\%) } & \multicolumn{3}{|c|}{ Technical Disponibility (\%) } & \multicolumn{3}{|c|}{ Operational Efficiency (\%) } \\
\hline & own & outsourcing & $\mathrm{tc}$ & own & outsourcing & $\mathrm{tc}$ & own & outsourcing & $\mathrm{tc}$ \\
\hline $\mathrm{A} \times \mathrm{A}$ & 83,03 & 83,82 & ns & 74,21 & 61,31 & $*$ & 62,08 & 51,32 & $*$ \\
\hline $\mathrm{A} \times \mathrm{B}$ & 83,03 & 75,61 & $*$ & 74,21 & 48,88 & * & 62,08 & 37,14 & $*$ \\
\hline $\mathrm{A} \times \mathrm{C}$ & 83,03 & 77,83 & $*$ & 74,21 & 55,81 & * & 62,08 & 43,71 & $*$ \\
\hline$A \times D$ & 83,03 & 78,95 & $*$ & 74,21 & 48,71 & $*$ & 62,08 & 38,41 & $*$ \\
\hline $\mathrm{B} \times \mathrm{B}$ & 89,10 & 75,61 & $*$ & 78,53 & 48,88 & $*$ & 70,01 & 37,14 & $*$ \\
\hline $\mathrm{B} \times \mathrm{C}$ & 89,10 & 77,83 & $*$ & 78,53 & 55,81 & $*$ & 70,01 & 43,71 & $*$ \\
\hline$B \times D$ & 89,10 & 78,95 & $*$ & 78,53 & 48,71 & $*$ & 70,01 & 38,41 & $*$ \\
\hline $\mathrm{C} \times \mathrm{C}$ & 86,83 & 77,83 & $*$ & 78,78 & 55,81 & $*$ & 68,41 & 43,71 & $*$ \\
\hline$C \times D$ & 86,83 & 78,95 & $*$ & 78,78 & 48,71 & $*$ & 68,41 & 38,41 & * \\
\hline $\mathrm{D} \times \mathrm{D}$ & 87,41 & 78,95 & $*$ & 73,82 & 48,71 & $*$ & 64,53 & 38,41 & $*$ \\
\hline
\end{tabular}

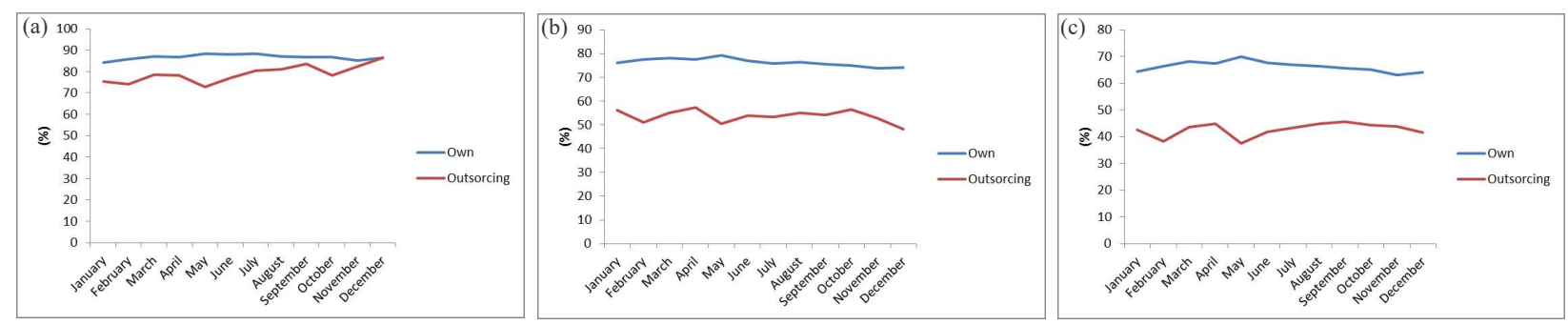

Figure 1 - Mechanical Availability (a), operational efficiency (b) and degree of utilization (c) for the cutting and processing during the year.

Figura 1 -Disponibilidade mecânica (a), eficiência operacional (b) e Disponibilidade Técnica (c) para as operações de corte e de processamento durante o ano.

the DM. The regional B with owned cut had the highest DM $(89,1 \%)$ while the same region with outsourced cut had the lowest value $(75,6 \%)$.

In a research done by Linhares et al. (2012), the authors had an $86,6 \% \mathrm{DM}$ to the harvester, this value was $2,5 \%$ lower than the lowest one found on this research to the own module and $10,9 \%$ higher to the outsourced modules. To Fontes \& Machado (2014) the ideal DM to forestall harvest should be around $92 \%$ to new machines and $85 \%$ of the ones with more use.

To the own module, the average to the regions were $65,97 \%$ and $41,04 \%$ to the outsourced. Alves \& Ferreira (1998) found a $72 \%$ EO, higher than the ones found to outsourced and lower to the values encountered in this research. At similar conditions, Cechin (2000) found a $68 \% \mathrm{EO}$, a higher value to both modules on this study.

On the same way, Silva (2011), found average percentual $85,79,70$ from the DM, EO and DT respectively.
It has been observed that those values are higher to harvest from own model at Region A and Region B and D outsourced.

The results proved statistically the superiority of the own services over the outsourced ones. Despite

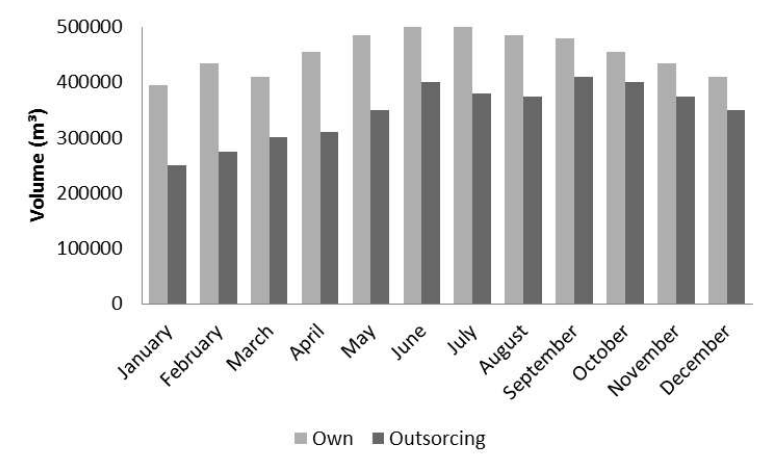

Figure 2-Monthly volume harvest in own and outsourcing modules.

Figura 2 - Volume mensal da colheita em módulos próprio e terceirizado. 
the different types of service, all the modules presented a program of corrective and preventive correction. However, such results of lower outputs for the outsourced modules may be directly related to the lack of qualified professionals for the maintenance, low quality of the used parts.

The harvesting machine DT during the months from 2013 (Figure 1), despite the superior results at the owned models from the outsourced, were more irregular during the months of the year when compared to the mechanical disponibility and operation efficiency.

The EO own modules (Figure 1), kept stable during the year and was superior to the outsourced modules during all the months. This can be in a relation of a better maintenance of infrastructure on the machines at the owned modules.

\subsection{Comparative between variables}

When comparing the EO values among the own and outsourced, a great differentiation between the averages was verified, being the own modules with superior income in all the regional and months of the year. In this sense, in Regional C, the own module with a mean of $68.41 \%$ had the best use of EO. In Regional D, the outsourced module, with a mean of $48.7 \%$, had the difference of $25.1 \%$ lower than the regional one with services performed by the module itself, and $30.1 \%$ in relation to Regional B.

Similarly to DM, DT and EO had higher values to the cut and processing when executed by an owned model in relation to the outsourced, the values were up to $32,8 \%$ more effective to the Region B when compared to the others, and the Region A had a better efficiency from $10,7 \%$ more than on the outsourced.

Through the amount of wood harvested during the one year period, a distinction was made between the own and outsourced modules in the same way as the DM, DT and EO analyzes. As shown in Figure 2 , the volume of wood harvested with its own modules was $1,234,310 \mathrm{~m}^{3}(23,0 \%)$ more than that produced by outsourced modules. The higher volume quantity harvested in the own modules may be due to a better quality of maintenance, adequate replacement of good quality parts, efficient transportation of machines and equipment between areas, among other factors.

\section{CONCLUSIONS}

- MD, TD and OE from the own models were superior comparing to the outsourced, leading to better output on the mechanizes harvest with owned machines.

- Among the regions, only A had a higher DM at the outsourced modules in relation to the owned.

- The harvest productivity of the own modules was higher than the outsourced modules in all months of the year, which demonstrates, in this case, a possible feasibility of the primary exploitation of the forest harvesting operational activities in this analyzed company.

\section{REFERENCES}

Alves MKL, Ferreira OO. Avaliação da etapa de descasque de toretes de eucalipto para polpa. Ciência Florestal, 1998;8(1):1-12.

Carmo FCA, Fiedler NC, Minette LJ, Souza AP. Otimização do uso do trator florestal forwarder em função da produtividade, custos e capacidade de carga1. Revista. Árvore. 2015;39(3):561-6.

Cechin FN. Análise da eficiência e do desempenho operacional das máquinas e dos equipamentos utilizados no corte raso de povoamentos florestais na região do planalto norte de Santa Catarina [dissertação]. Curitiba: Universidade Federal do Paraná; 2000.

Fontes JM, Machado CC. Manutenção mecânica. In: Machado CC. Colheita florestal. $3^{\text {a }}$.ed. Viçosa, MG: 2014. p.243-91.

Linhares M, Sette Júnior CR, Campos F, Yamaji FM. Eficiência e desempenho operacional de máquinas harvester e forwarder na colheita florestal. Pesquisa Agropecuária Tropical. 2012;42(2):212-9.

Leite AMP. Análise da terceirização na colheita florestal no Brasil [tese]. Viçosa, MG: Universidade Federal de Viçosa; 2002.

Machado CC, Lopes ES. Análise da influência do comprimento de toras de eucalipto na produtividade e custo da colheita e transporte florestal. Cerne. 2000;6(2):124-9.

Machado CC, Lopes ES, Birro MHB, Machado RR. Transporte Rodoviário Florestal. $2^{\mathrm{a}}$.ed. Viçosa, MG: 2009. 217p. 
Machado CC. Colheita florestal. $3^{\mathrm{a}}$.ed. Viçosa, MG: UFV; 2014. p.543.

Oliveira D, Lopes ES, Fiedler NC. Avaliação técnica e econômica do Forwarder na extração de toras de pinus. Scientia Forestalis. 2009;37(84):525-33.

Silva EN, Machado CC, Fiedler NC, Fernandes HC, Paula MO, Carmo FCA et al. Avaliação de custos de dois modelos de harvester no corte de eucalipto. Ciência Florestal. 2014;24:741-8.

Schuchovski MS. Diagnóstico e planejamento do consumo de madeira e da produção em plantações florestais no Estado do Paraná [dissertação] Curitiba: Universidade Federal do Paraná; 2003

Silva EN. Avaliação técnica, de custos e ambiental de dois modelos de harvester na colheita florestal [tese] Viçosa, MG: Universidade Federal de Viçosa; 2011. 